\title{
Activist Materialism
}

\section{Dimitris Papadopoulos University of Leicester}

\begin{abstract}
This paper explores a form of activism that operates with and within matter. For more than 150 years materialism has informed activist practice through materialist conceptions of history and modes of production. The paper discusses the ambivalences of these previous configurations of activism and materialism and explores possibilities for enacting activist interventions in conditions where politics is not only performed as a politics of history but as the fundamental capacity to remake and transform processes of matter and life. What is activism when politics is increasingly performed as a politics of matter? What is activism when it comes to a materialist understanding of matter itself?
\end{abstract}

Keywords: activism, materialism, matter, Marx, minor science, technoscience

\section{1844}

The real unity of the world consists in its materiality... (Engels 1987 [1878])

The recent resurgence of materialism poses questions about its implications and relevance for politics. Rather than addressing institutional or representational politics I am interested here in tracing the connections of materialism to the transformative politics of social movements: collective direct activism on the immediate level of social and material life. In each particular historical chronotope there is a distinctive set of social movements which become capable of initiating social change. How is materialism related to these transformative

Deleuze Studies Volume 4: 2010 supplement: 64-83

DOI: $10.3366 / \mathrm{E} 1750224110001133$

(C) Edinburgh University Press

www.eupjournals.com/dls 
forces? And what kind of political activism do today's novel forms of materialism promote?

The articulation between materialism and activism is unstable, full of discontinuities and breaks. It is in Marx and the early rebellions that took place in the 'New World', and in the Communes and uprisings across Europe, that materialism first becomes directly linked to political activism: activist materialism. Since then materialism has been the target of interrogation not only from idealist positions and various dualist ontologies but also more recently from within the very political forces of the western post-1960s Left which were embracing materialism in one form or another. Critiques from the Left did not position themselves outside the materialist movement, they were not first and foremost an opposition; rather, it was an immanent movement enunciated from the very core of materialism itself that lasted up until the 1980s and 1990s and finally ushered a new version of materialism to the fore. Deleuze and Guattari's work exercised an important influence on the movements that attempted to rework materialism. During the long history of the encounter between materialism and activism both of them changed meanings, and each new formation of the one influenced the meaning of the other, producing new configurations of social practice.

Marx's work is probably the first attempt to connect activism and materialism on the level of everyday political practice. The Theses on Feuerbach exemplifies the articulation between materialism and activism in a remarkable and equally unexpected way. Thought objects and abstract contemplation are what Marx tries to defy, that is, idealism. The movement which changes society is the movement which opposes idealism. It is real, objective, that is, material, says Marx. Marx's materialism is conceived as sensuous everyday practical activity which has the capacity to change the material conditions of existence. The moment of transformation is the moment when, to use Marx's term, civil society collapses and a new social material order emerges. This very modern understanding of materialism was epitomised in The German Ideology: here communism is not 'an ideal to which reality have to adjust itself'; it is 'the real movement which abolishes the present state of things' (Marx and Engels 1846: 48).

It is in the Economic and Philosophical Manuscripts (1844) that Marx introduces a new definition of materialism grounded on inserting political activism into the understanding of materiality. Here he uses the concept of 'species-being' to describe human activity as the process of the self-making of the human species in a direct practical and organic relation to other species and the whole of the natural world. Despite 


\section{Dimitris Papadopoulos}

its essentialist connotations, 'species-being' is as close as one can get to a radical understanding of a form of self-instituted collective emancipation in which cooperation and interaction among humans as well as between humans and the material world is crucial (Dyer-Witheford 2006). For Marx the question is to uncover both what impedes this process, i.e. how capitalist labour alienates 'species-being', and how collective material self-transformation is possible. Who controls the process of material transformation, who participates and in which position, are questions which drive Marx's activist reading of materialism. This materialism is activist because it is a 'life activity', in the literal sense: 'life engendering life'. There is no social transformation outside of the material realm.

Marx's early materialism avoids the pitfall of epistemology: the attempt to distinguish between a strong materialist perspective which gives absolute primacy to matter (all that exists is matter) and a weak materialist perspective that puts the emphasis on how we conceive matter (all that exists is dependent on matter). Such an epistemological definition of materialism wouldn't be sufficient to distinguish it from idealism because at the end what we define as matter would involve an idealist move. From an epistemological viewpoint both positions, the materialist as well as the idealist one, are in principle tenable. But Marx's early materialism is ontological through and through: there is no transformative activity which is non-material. Since activity is inherently material, matter itself cannot be conceived as an outside or as an object of human practice: matter is humanity's body. 'Speciesbeing' is the collective metabolic transformation of matter: activist materialism. There is a monist understanding of matter here that resonates with today's neo-materialism (for a superb example of the new materialism see Bennett 2010), so much influenced by Deleuze and Guattari's work which will be discussed extensively later in the paper. For now we can say that both Marx's early materialism and today's neo-materialism share a strong emphasis on matter as a vital force: inorganic matter as well as biological and social life are movements of matter itself. Nevertheless, in terms of Marx's early definition of materialism, merely highlighting the importance of materiality as an assemblage of heterogeneous forces is not enough to account for the kind of transformative political engagement that was his main concern. Marx's monist ontological materialism is infused with an activist dimension which takes place on the actual everyday life of 'species-being': the collective capacity to affect material change. Marx's ontological reading of materialism is one that focuses on practice, but a form of practice which is not solely in the hands of people but also 
depends on non-human forces ('nature'). Practice and matter cannot be thought independently. And the reason for this is not epistemological but political: activist materialism is a response to capital's breaking up of the 'species-being' into classes and races. Materialism without activism is not transformative, in fact it is impossible. This is the quintessence of Marx's early account of a practical ontology and an activist materialism. What happens to this configuration of materialism 34 years before the bicentenary anniversary of the Economic and Philosophical Manuscripts?

Marx's and in particular Engels' late work contains a second reading of the activist materialism developed in their early writings: dialectical materialism. 'Diamat' consolidated the absolute emphasis on matter but introduced a different conception of its role which had tremendous impact on theorists of the Second International and the emerging Marxist social movements. 'Diamat' foregrounded activist materialism as a rather dogmatic epistemological doctrine that gradually removed the practical ontological concern with matter and subsequently transformed the meaning of activism. Already in the early writings there are numerous instances where, instead of the practical ontology described in the previous paragraphs, we find a relation to nature dominated by the ideal of progressivism and the total human mastery of nature's laws. This understanding also changed the meaning of activism. In Anti-Dühring (1878) and Ludwig Feuerbach (1886) Engels set out a materialist cosmology that served to define activism as a political practice which is mono-causally determined by a set of laws extracted from nature: historical materialism. This is characterised by both a bifurcated dualist ontology-with objective material reality and its inherent laws on the one hand and social practice on the other-and also by a reduction of materiality to human social institutions and structures. Activism was reduced to the efficacy of changing social structures. Historical materialism announces the erasure of the activist materialism to be found in the early works of Marx and Engels.

\section{1908}

Moscow! Moscow! Moscow! (Irina in Chekhov 1900)

In Materialism and Empirio-Criticism Lenin follows this line and conceives materialism exclusively as a theory of knowledge. He writes: "For the sole "property" of matter with whose recognition philosophical materialism is bound up is the property of being an objective reality, of existing outside our mind' (Lenin 1908: 260). Materialism here starts 


\section{Dimitris Papadopoulos}

from the assumption of an ontological duality, two separate entities: matter on the one hand, mind on the other. Lenin reduces materialism to gnosiological realism, while the activist materialism of the early Marx was one which asserted a monist ontology: mind is matter, the unity of the world is sustained by its materiality and the immanent action of matter and mind alike. Lenin's approach is a radical departure from a position which is concerned with bringing together practice and matter. Rather, his concern was to develop a conceptual instrument which splits ideas in two opposite camps. While Marx and Engels' early activist materialism was concerned with how matter is changing and can be changed, Lenin's materialism was developed as a strategic tool for the selection of the social and political forces of his time which might potentially transform into a revolutionary historical subject.

Lenin was building a war machine. He was trying to develop a philosophical conception of materialism which had no other target than to reveal the functioning of a deep social dichotomy between the working class and capital (for an extended analysis of these issues see Jordan 1967). His only goal was to submit theory to the everyday requirements of his revolutionary practice. This was truly phenomenal and unparalleled (albeit fatal). With his philosophical work Lenin developed a tool to extend the social division as far it could go, to the far end of mind and the history of ideas. In the unsurpassable What Is To Be Done? (1902) Lenin claims that social conflict penetrates every corner of society, every social relation, every idea. Nothing is untouchable by class antagonism, it takes a partisan organisation and a revolution to change it. This is partisan philosophy and partisan practice. And it is a truly activist move; however this particular move enacts a different materialism. It is carried out in the name of materialism but it is not an activist monist materialism. It is one which subsumes matter and dominates nature in the name of historical progress. If Marx's early materialism was of a kind which proclaimed the irresistibility of revolution on the grounds of a unified monist movement of matter and activism, Lenin's materialism is dualist, elevating irresistibility to something completely different: the will for action.

'Materialism must be a form of idealism, since it's wrong-too' (Sahlins 2002: 6). Marshall Sahlins' aphorism concentrates the postSecond World War predicament with the configuration of an activist materialism à la Lenin. Lenin's reduction of monist materialism to gnosiological realism had far-reaching consequences for the philosophical scaffolding of the social forces which found themselves entangled in the Marxist enterprise and in the emerging working-class 
movements from the beginning of the twentieth century up to the 1970s and 1980s. The most important consequence was that gradually materialism failed to contribute to an ethical and political programme for the everyday enactment of activist practice. Activist materialism became everything but activist, quickly turning into an ideology of state socialism and an abstract philosophical system. In the post-Second World War period, materialism gradually lost its strength as an ethical project for revolutionising everyday practice.

\section{1977}

Always historicize! (Jameson 1981)

The end of the 1970s probably saw a peak in the process of an immanent critique of materialism which rendered visible its contradictions as inherited from the Leninist period. The following quote from Raymond Williams displays the state of thought and mood among politically committed left intellectuals at the time:

It took me thirty years, in a very complex process, to move from that received Marxist theory (which in its most general form I began by accepting) through various transitional forms of theory and inquiry, to the position I now hold, which I define as 'cultural materialism'. The emphases of the transition-on the production (rather than only the reproduction) of meanings and values by specific social formations, on the centrality of language and communication as formative social forces, and on the complex interaction both of institutions and forms and of social relationships and formal conventions-may be defined, if any one wishes, as 'culturalism', and even the crude old (positivist) idealism/materialism dichotomy may be applied if it helps anyone. What I would now claim to have reached, but necessarily by this route, is a theory of culture as a (social and material) productive process and of specific practices, of 'arts', as social uses of material means of production. (Williams 1980: 243)

During the period of the crisis of materialism which unfolded in the decades between 1950 and 1990 the notion of culture reordered the existing meanings of materialism and fuelled the development of a new constellation of concepts and activities into the heart of the social conflict of the post-war period. Of course, not all of the various movements and critiques of materialism embraced the notion of culture. The point here is not to unify these extremely diverse movements and traditions under one overarching rubric. Rather, what is of importance is that the insurgency against the previous materialism evolved in proximity to new everyday activities whose many faces and actions pertain to changing cultural power (see Gilbert 2008; Papadopoulos, Stephenson and Tsianos 2008). 


\section{Dimitris Papadopoulos}

This turn to culture thoroughly changed the way political activism is performed, moving the target away from the state itself towards power's pervasive materialisation in the whole societal nexus: in terms of gender relations, racialisation processes, social institutions, social and civil rights, the political representation of excluded groups, and so on. Many societies, many cultures, many socialisms, Raymond Williams would have said. This remaking of materialism corresponds with the practices of new social forces that found themselves outside the traditional organisational forms of the working-class movement which appeared as the inheritor of the materialist politics of the previous periods. The new politics of cultural counterinsurgency, not least as exemplified in the new youth cultures of the 1960s and the variously globalised events of 1968, spread across the globe with a velocity far beyond the wildest utopian dreams that Soviet propaganda bureaucrats and western communist parties ever imagined for their own materialist politics (see Connery 2005).

But where exactly was the materialism in this activism which propelled itself through cultural politics? The most likely answer is that there was very little materialism in this 'cultural materialist' politics, at least not in the sense of an activist and practical ontology concerned with a monist understanding of matter (as in Marx's early version). Nor was there much of the materialism of the late Marx/Lenin period with its strong focus on gnosiological dualism and the efficacy of social structures. Cultural politics questioned both versions of materialism and developed along many disparate and diverse paths: all of which were, however, occupied with the centrality of representation and its critiques. 'Discourse' seems to have been one of the paths that helped this move. Ironically, the discursive turn and the turn to language set in motion an activist politics which followed the activist materialism of the previous decades. Umberto Eco's The Open Work (Eco 1989) and James Clifford's collection Writing Culture (Clifford and Marcus 1986), as well as the broader linguistic turn (Rorty 1967) and the interest in hermeneutics (Gadamer 1989), are just some examples of intellectual engagements that marked the path to the undiscovered continent of representation. It was through the changing of meanings and the challenging of representations that the very process of social activism was now being performed.

Another important path for the revision of materialism that developed during this period came from an interest in social space as a key battlefield for social antagonisms. How is space regulated, appropriated and re-appropriated by marginalised social groups? Marxist inspired 
readings of everyday space (Lefebvre 1991), the situationist movement (Debord 1981), and cultural geographers (Harvey 1990) all turned to kaleidoscopic remakings of space in order to articulate an everyday, mainly urban, activism that made radical interventions in the politics of post-war Europe and North America possible. The attention to space as lived experience is closely related to body politics. The body becomes an open substratum for the inscription and re-inscription of social signification. In this sense signification moves from the mind itself to the body and emerges in a process of subjective embodiment through a social context (cf. Csordas 1994; Harré 1996; Overton 1998) or through cultural-political constellations (cf. Bourdieu 1987; Braidotti 2002; Fausto-Sterling 2000).

But actually what the activism of the post-war period was mainly preoccupied with was subjectivity and difference (Blackman et al. 2008). As cultural studies has so vividly shown, subjectivity is always in the making because it entails a non-expressed otherness, a non-discursified and imagined possibility of social relations (Hall 1990; Papadopoulos 2006). Such a theoretical move was particularly important in a period where identity politics occupied a central place in the political life of the societies of the Global North (Clifford 2000). Already in the 1970s and 1980s, cultural studies, feminist politics, anti-racism and gender studies identified the limitations of an activist materialism qua Lenin which saw social consciousness either as committed to working-class change or as wrong and ideological. In resonance with Althusser's take on ideology (Althusser 2001), new social movements focused on the emergence of multiple political subjectivities that defy straightforward classification as wrong (false consciousness) or right (revolutionary) according to previous conceptions of activist materialism. Crucial for this attempt was the process of articulation (Clifford 2001; Hall 1986a; Slack 1996). Activism here is conceived as a movement of articulation which by rethinking Gramscian hegemony attempts to contest domination through 'rendering the symbolic increasingly dynamic, that is, by considering the conditions and limits of representation and representability as open to significant rearticulations and transformations under the pressure of social practices of various kinds' (Butler 1997: 23; see also: Hall 1986b; Laclau and Mouffe 1985). This understanding of political subjectivity as subjectification and the result of articulation is what essentially captured activist practices in this period, positioning subjectivity in the tension between coercion by institutional mechanisms and articulation through them. 


\section{Dimitris Papadopoulos}

Cultural politics challenged previous versions of materialism on the grounds of an increasing diversification of social strata and classes. It is this diversification that brought a new form of activism which, rather than focusing on materialism was concerned with the fight for representation. In this struggle, discourse, space, body and subjectivity are approached as constitutive of an oppositional politics of difference. Cultural studies, women's studies, postcolonial studies and queer politics have all participated in and critiqued this fight for representation (see Hall and Jefferson 1976; Clifford 1986; Sedgwick 1990; Spivak 1999; Warner 1999; Butler, Laclau and Žižek 2000; Mouffe 2000). The importance of representation comes from the dissolution of social class as the central actor and political force in society. The political order of transnational neoliberal societies is an order which is supposed to be occupied by multiple players working to foster alliances between themselves and to establish new relations of power. And it is precisely this form of relationality which triggers the imperative for representation (Stephenson and Papadopoulos 2006). Representation enters the realm of politics as the attempt to give voice and operative agency to social groups who have been excluded by the politics of the traditional versions of activist materialism. We can trace the singular trajectories of these emergent oppositional subjectivities of new diverse social groups in civil rights movements, in the events of 1968, in feminist movements, antiwork movements and new forms of social cooperation, in the 1960s cultural rebellions and in the fight against colonialism and racism.

\section{1987}

The only enemy is two. (Deleuze 2001)

However deep the break between Leninist activist materialism and the cultural materialism of the post-war period might be, there remains nevertheless a peculiar form of continuity. Lenin's materialism reduced activism to the radical intentionality of a subject determined to reflect the antagonistic conditions of existence. Cultural materialism retained this reduction but introduced a differentiation with respect to the subject itself. Instead of a unified self-identical subject we now have a plethora of subjectivities and of possible contexts in which they are constituted. This break implied a deep change in the way political activism was conceived: Leninist activism subsumed every activity under a single social conflict between labour and capital, while the activism of cultural politics multiplies the fronts on which social antagonisms are encountered and 
fought. Nevertheless, despite this radical break, both positions retain a strange commitment to epistemological dualism. Representation and ideas are the battleground on which the conceptualisation of activism thrives. It is about negotiating and transforming the conditions of thinking and feeling that make activism possible. In a peculiar way cultural materialism followed Lenin's path in focusing on how we represent reality. What cultural materialism introduced was a new conceptualisation of the main determinants of representation. It is no longer the class structure of society but rather the endless variability of social contexts that allows different configurations of representation. In this sense the question for cultural activism becomes one of how reality is constructed in the subject itself, or 'social constructionism'. In both positions, however, practice and matter are subsequent to ideas; and despite their pervasive critiques of dualism, both retained a dualist ontology. Here is Deleuze and Guattari's well-known diagnosis of this situation:

We invoke one dualism only in order to challenge another. We employ a dualism of models only in order to arrive at a process that challenges all models. Each time, mental correctives are necessary to undo the dualisms we had no wish to construct but through which we pass. Arrive at the magic formula we all seek-PLURALISM=MONISM - via all the dualisms that are the enemy, an entirely necessary enemy, the furniture we are forever rearranging. (Deleuze and Guattari 1987: 20)

In much of their work, and most centrally in A Thousand Plateaus, Deleuze and Guattari introduce a monist materialism which attempts to rehabilitate matter from its enslavement in representation. Their move is co-extensive with the (re-)appearance of a form of materialism that puts the primacy of matter on the agenda of political practice and theory after the 1990s and creates the possibility for the emergence of a novel configuration of activist materialism. Strangely enough it was the poststructuralist faction of the cultural activism of the previous decades that prepared the way for this move-in particular feminist materialism, the attention to the body, as described earlier, and the persistent but evasive attempts to put materialism back on the agenda (one need only recall Althusser's (2006) subterranean movements). But even more crucial to the reinvigoration of activist materialism is the increasing impact of scientific knowledge on everyday life and on the structures of production in the Global North that posit matter as an active, self-ordering, emergent player in a radically post-human world (see Papadopoulos 2010). Matter is before thinking, matter is in 


\section{Dimitris Papadopoulos}

thinking, matter is everywhere. For Deleuze and Guattari there is no empty space, there is always matter and matter is always differentiated. Representations are a particular form of differentiation in their own right, they do not exist prior to or vis-à-vis matter. Representations are movements of matter as much as genetic mutations or geological movements are. Deleuze and Guattari's point is not to eliminate the distinctive importance of representations and ideas, rather, their claim is that when representations are considered as separated from matter they become strategic tools for ordering material reality. Representations are closures and reterritorialisations that are used as powers to organise matter in a particular way.

The materialism emerging gradually after the 1990s focuses on the question of monism instead of concentrating on the binary opposition between materialism and idealism. It is this very dichotomy that undermines monist materialism. It is not about which position you take in this thinking, it is about the very act of taking a position. For Deleuze and Guattari the real enemy of materialist thinking is not idealism, it is dualism. 'The only enemy is two' (Deleuze 2001: 95). Materialism after the 1990s is an anti-dualism that gradually transforms the relation between activism and materialism that informed most of social movements during the Leninist period and after: matter and mind, activism and materialism start to fuse again into one process. The practice itself, the site of action and its thinking, gradually became equally important for the activism of the 1990s. It is not a coincidence that many of the social movements of this period and since focus on the question of reclaiming. The activism of reclaiming attempts to re-appropriate the immediate spaces of existence by simultaneously transforming them through everyday actions: reclaim the streets, reclaim the city, earth activism and the permaculture movement, the remaking of transnational spaces through migration movements, radical queer activism and the building of new social relationalities and communities, cyberactivism, the alter-globalisation movement, the production of the commons. In all of them we encounter an emphasis on reclaiming material spaces and relations vital for developing new alternative social and material projects (for an extended discussion see Papadopoulos et al. 2008; Chesters and Welsh 2006). This was, of course, also a central characteristic of previous forms of political activism, in particular of feminism. But the primary difference here is that either the question of reclaiming social and material spaces was not conceptualised as such or else was considered secondary with regards to the 'real' and 'primary' struggle, which was supposed to focus on radical demands addressed to 
the state and its institutions in respect of recognition and representation. In contrast, the activism emerging after the 1990s, and in particular since the Zapatista movement, is less concerned with the state's mediation; instead it consciously attempts to force existing institutions to change by creating alternative materialities and forms of life.

Deleuze and Guattari's monist materialism captures a key moment of this form of activism that reconnects us with the activist materialism of the early Marx described at the beginning of this paper. It is the question of how to change matter and create new forms through collective practices. Deleuze and Guattari's materialism questions how the very moment of morphing matter comes into being. The emergence of form is neither the transcendent imposition of a preconceived plan on matter-forget the architect and the bee-nor is it simply a movement of self-organised matter that becomes represented in the mind of the subject-forget autopoietic systems. Neither external plan, nor internal self-organisation. In this sense, it is neither idealism nor materialism (as conceived until now). The position Deleuze and Guattari try to develop is that it is the movement of matter itself that makes both a materialist as well as an idealist stance possible. Both the capacity to create form and the capacity to understand the emergence of form are immanent to existence. There is no monism if there is a dualist option; 'there is nothing that is one, there is nothing that is multiple' (Deleuze 2001: 99). Deleuze and Guattari tried to avoid thinking along the either-or of materialism and idealism/dualism. The very possibility of thought is immanent to matter's movements.

Morphogenesis in Deleuze and Guattari is neither a property of selfordering material systems nor the result of a vitalist force that initiates material change; nor of course is it the ability of the subject's mind to form matter according to a preconceived plan. There is something not immediately present in the actuality of material flows-something virtual - that makes matter congeal into stratified stable forms. In each particular setting there is a virtual ordering principle (an abstract machine in Deleuze and Guattari's words) that links and connects flows and properties of matter. An often utilised example in A Thousand Plateaus is the organism. When does an aggregate of various bodily processes and functions become a thing which can be called an organism? An organism is ordered matter-the moment when matter in flux, in movement, in variation becomes a discernible thing amenable to intervention, management, manipulation (through medical practice for example, or in the course of ontogenetic development). Embryology and biology, medicine and psychology, play an equal role with ontogenetic 


\section{Dimitris Papadopoulos}

change, gene activity, epigenetic interactions and the environment to produce a coherent story of what an organism is in a particular historical chronotope. Out of the movement of unformed matter and non-formalised processes of the body without organs $(\mathrm{BwO})$, as Deleuze and Guattari call the non-organismic body, we encounter the formed and stratified form of the organism:

The organism is not at all the body, the $\mathrm{BwO}$; rather, it is a stratum on the $\mathrm{BwO}$, in other words, a phenomenon of accumulation, coagulation, and sedimentation that, in order to extract useful labor from the $\mathrm{BwO}$, imposes upon it forms, functions, bonds, dominant and hierarchized organizations, organized transcendences. The strata are bonds, pincers. 'Tie me up if you wish.' We are continually stratified. But who is this we that is not me, for the subject no less than the organism belongs to and depends on a stratum? (Deleuze and Guattari 1987: 159)

In this understanding of monist materialism, matter becomes the horizon and the substratum on which an alternative to the previous versions of materialism can emerge. Matter becomes (once more) the way to reconnect activism and materialism. The crucial move for materialism since the 1990s is to seek in matter an escape from a situation where the demise of the everyday transformative activist aspect of materialism became so pervasive. Deleuze and Guattari's move to a monist materialism is not a theoretical choice; it is the result of a political diagnosis according to which any desire for change has been vampirised by the institutions of the state. Even more than that, in the previous decades desire itself has been transformed into a capitalist institution (cf. Holland 2005). Every social struggle is reinserted as a rejuvenating feature of capitalist production, every social innovation is made productive. The story of the twentieth century is not a history of revolutions; it is rather a history of counter-revolutions (Müller 2000) where every desire has been appropriated, regurgitated and effaced by capitalism. The bottom line for Deleuze and Guattari's take on materialism, as a monist materialism based on a renewed attention to matter, is the attempt to reactivate the transformative force of desire. Deleuze and Guattari try to do this by breaking the link between 'desire' and 'desire for'. Every 'desire for' is a closure: desire for revolution, desire for mastering nature, desire for recognition, desire for an identity, desire for not having an identity, desire for desire. This is the political move Deleuze and Guattari reinsert into the new materialism: to disrupt the view that the creativity of people, animals and matter can be viewed as a desire which can always be folded back into capitalist domination 
and valorisation. Every 'desire for' is already captured and appropriated. This is the spell capitalism casts upon life.

The key political ingredient of monist materialism is that desire needs to be disarticulated from its essential function as something which has a target and object. The diagnosis: 'desire for' is the way capitalism revolutionises itself. The radical political key to monist materialism is that it allows desire to be engendered in a way that can move beyond its recoding into the political closures of the counter-revolutions of the twentieth century. The prominent role of matter in Deleuze and Guattari is a small gesture of rebellion against the capture of earlier materialisms within a docile machine for constantly revolutionising capitalism. Deleuze and Guattari perform this small gesture of freedom by inserting indeterminacy into the way desire operates; and they do so by turning to the underlying indeterminacy of matter: matter is primarily unformed and in continuous variation, an oscillation between various intensities, closures and openings. Matter is a political exit. Matter is escape. The making of a life. Matter can break the capitalist spell.

The turn to matter becomes political when it is articulated in relation to this understanding of desire. That is why, despite the various attempts to read Deleuze and Guattari's materialism in a scientistic way-that is, as a cosmology attentive to science (see for example De Landa 1997) - what Deleuze and Guattari propose is a rather minor move, one which attempts to interrupt the appropriation of desire by grounding it in the indeterminate movements of matter. Deleuze and Guattari refer to this move also as a science but crucially a minor science (or a nomad, ambulant, itinerant science). In Proposition III of the War Machine chapter in A Thousand Plateaus they describe this as a practice which follows matter's immanent traits, confronts problems instead of applying theorems, pushes matter to the next threshold, connects practical effects and affects of practice. Against a science of matter or a technology to control it, Deleuze and Guattari emphasise practice as the key dimension of a minor science that knows how to surrender to matter. Minor science is a practice which is essentially experimental; rigorous but not systematic, it directly links activity with matter. It is here that the neo-materialism of the 1990s and after can once again become activist, with minor, nomad science on the one hand and the big, royal, imperial science of the state on the other: 'What we have... are two formally different conceptions of science, and, ontologically, a single field of interaction in which royal science continually appropriates the contents of vague or nomad science while nomad science continually cuts the contents of royal science loose' (Deleuze and Guattari 1987: 367). If 


\section{Dimitris Papadopoulos}

there is to be an activism of neo-materialism it will be developed in the decades to come from the practices of the nomad scientist, the artisan who operates within the constraints of matter, who follows singular material possibilities, and who thereby escapes state striation.

\section{2027}

Among the tortures and devastations of life is this then-our friends are not able to finish their stories. (Woolf 1992)

Minor science is embedded in a reality primarily defined by the centrality of scientific knowledge for the making of a polity in the societies of the Global North. Politics are increasingly performed through science itself (cf. Papadopoulos, forthcoming 2011). Physical, biological, chemical bodies can be thought as political in their own right (Protevi 2001). Minor science can respond to this tight articulation of politics and scientific knowledge. Simultaneously scientific knowledge is a constitutive element of a transformation traversing the societies of the Global North by becoming increasingly distributed in society (the socalled 'knowledge society'). The figure of the 'socialised worker' (Negri 2005) captures this move to a mode of production and circulation based on the valorisation of the totality of life and the intellectual creativity of the individual worker. In this context, scientific knowledge on the one hand becomes explicitly political and, on the other, permeates a wider range of social strata than ever before in the Global North.

Minor science is part of the social material conditions prevailing today; it operates below and outside state science and yet, as discussed in the previous section, it is continuously under pressure to be absorbed into the big science of the state.

The fact is that the two kinds of science have different modes of formalization, and State science continually imposes its form of sovereignty on the inventions of nomad science. State science retains of nomad science only what it can appropriate; it turns the rest into a set of strictly limited formulas without any real scientific status, or else simply represses and bans it. (Deleuze and Guattari 1987: 362)

Even the very idea of minor science itself can be buried under the desire for the new grand theory which can be assimilated into state science. The minor science of matter can be deployed to support a new grand system of thought; a grand theory that uses all the fashionable and marketable concepts and ideas circulating today-complexity, event, affect, multiplicity, networks, assemblages, etc. - to create a new 
meta-framework with which to approach the world. Cosmopolitical assembling as a new cosmology. A new abstract theory. Producing a new grand theory is one possible trap for today's minor science. A Deleuzian century? This would be the end of every inspiring and transformative potential of today's neo-materialism. The unfinished story of contemporary minor science is that it can so easily become absorbed into the workings of state science, that is, become a 'desire for' a grand system, a philosophical materialism devoid of its activist element. This kind of philosophical materialism will then become nothing but a form of governance of things and events. Latour the governor, Badiou the priest, Žižek the buffoon: actors in the imperial court in which state science feeds on the practices of minor science to produce a new cosmology that shapes technoreality.

Minor science and state science are inextricably bound together. In fact, minor science exists in the very core of state science. Pamela Smith has shown how artisan production-probably the most vital aspect of minor science-was crucial for the emergence of the rationalist objectivist scientific world-view which came to dominate the western world increasingly after the sixteenth century. It was the artisans' work, an intellectual revolution from bottom up, that 'transformed the contemplative discipline of natural philosophy into an active one' (Smith 2006: 239). Artisan science was later codified and appropriated into a new disembodied epistemology of experimental science. But experimental science never abandoned artisanal production. In fact experimental science and imperial science always rely on artisanal production and the minor science of matter. It was thanks to the purported modesty of meticulous artisanal efforts that Boyle's bottomup experimental laboratory science won out over Hobbes' top-down geometric science (Shapin and Schaffer 1985; Haraway 1997).

This is even more the case today. In experimental science, the 'discovery' of 'natural facts' and 'realities of matter' was a distinct procedure that preceded possible technological applications. With the rise of technoscience, such applications become the very drive behind basic research. Discovery is fabrication. Science is not about observation but about modification. This situation creates an even more intense pressure for maintaining minor science, making it part of the fast-moving world of technoscientific research. In other words, one of the main characteristics of minor science-its interventionist, direct, ambulant quality - is now a dominant feature of technoscience itself. Propelled by the post-Second World War rise of big science, the later proliferation of the assembly-line industrial scientist (see Shapin 2008), the spread 


\section{Dimitris Papadopoulos}

of an entrepreneurial scientific culture, the neoliberalisation of research culture and the precarisation of intellectual and affective labour, science and its applications increasingly fold into each other. Minor science fuels the everyday workings of contemporary technoscience.

Scientific practices and objects are as much the result of artisanal work as they are of the precarised labour of industrial scientists and of the entrepreneurial investments of corporate and state science. The problem is not so much that minor science and state science meet and collide - an image which Deleuze and Guattari have pictured in their all too typical masculinist reading of science as an agonistic field in A Thousand Plateaus. Rather, minor science and state science co-constitute what Donna Haraway calls zones of implosion where the boundaries between human and non-human, nature and artificiality, are meaningless: 'the chip, gene, bomb, fetus, seed, brain, ecosystem, database'. Such imploded technoscientific objects make up the conditions of our actual material presence in the world, they are 'wormholes that dump contemporary travelers out into contemporary worlds' (Haraway 1997: 43).

The entanglement of minor and state science is the very reality in which our material existence unfolds. In these conditions the crucial challenge for minor science is to engage with radical activism again. Among the questions this activism is facing today are the following: How can minor science contribute to the immediate making of liveable words (Haraway 2007; Puig de la Bellacasa 2010; in press)? How can justice be inscribed in relation to our technological objects, our cells and organs, the water, the air, the soil? And how can material justice be instigated in a non-dualistic manner?

As minor science implodes into big state science and itself tends towards a grand system of thought, rather than theorise this implosion, it may be we need to fabulate. Thriving in communities which will only selectively make use of big state science the new activisms that will emerge in the decades to come will be truly operating on the level of matter. They will mobilise radical political interventions through intraacting with and within matter. The remaking of matter engenders radical liberation projects. And thus perhaps our almost 200-year-old tale of emancipation will happily become a reality.

\section{Note}

I am grateful to Marcelo Svirsky for his insightful suggestions and encouragement. Special thanks go to Maria Puig de la Bellacasa, Hywel Bishop and Jan L. Harris for their critical engagement with the text. 


\section{References}

Althusser, Louis (2001) 'Ideology and Ideological State Apparatuses: Notes Towards an Investigation', in Lenin and Philosophy, trans. B. Brewster, New York: Monthly Review Press, pp. 85-126.

Althusser, Louis (2006) Philosophy of the Encounter: Later Writings, 1978-1987, trans. G. M. Goshgarian, London: Verso.

Bennett, Jane (2010) Vibrant Matter: A Political Ecology of Things, Durham, NC: Duke University Press.

Blackman, Lisa, John Cromby, Derek Hook, Dimitris Papadopoulos and Valerie Walkerdine, (2008) 'Creating Subjectivities', Subjectivity, 22, pp. 1-27.

Bourdieu, Pierre (1987) Sozialer Sinn: Kritik der Theoretischen Vernunft, Frankfurt am Main: Suhrkamp.

Braidotti, Rosi (2002) Metamorphoses: Towards a Materialist Theory of Becoming, Cambridge and Malden, MA: Polity/Blackwell.

Butler, Judith (1997) 'Against Proper Objects', in E. Weed and N. Schor (eds.), Feminism Meets Queer Theory, Bloomington, IN: Indiana University Press, pp. $1-30$.

Butler, Judith, Ernesto Laclau and Slavoj Žižek (2000) Contingency, Hegemony, Universality: Contemporary Dialogues on the Left, London: Verso.

Chekhov, Anton P. (1900) Three Sisters, Oxford: Oxford University Press.

Chesters, Graeme and Ian Welsh (2006) Complexity and Social Movements: Multitudes at the Edge of Chaos, London: Routledge.

Clifford, James (1986) 'Partial Truths', in J. Clifford and G. E. Marcus (eds.), Writing Culture: The Poetics and Politics of Ethnography, Berkeley: University of California Press, pp. 1-27.

Clifford, James and G. E. Marcus (eds.) (1986) Writing Culture: The Poetics and Politics of Ethnography, Berkeley: University of California Press.

Clifford, James (2000) 'Taking Identity Politics Seriously: 'The contradictory, stony ground...', in P. Gilroy, L. Grossberg and A. McRobbie (eds.), Without Guarantees: In Honour of Stuart Hall, London and New York: Verso, pp. 94-112.

Clifford, James (2001) 'Indigenous Articulations', The Contemporary Pacific, 13:2, pp. 468-90.

Connery, Christopher (2005) 'The World Sixties', in R. Wilson and C. Connery (eds.), Worldings: World Literature, Field Imaginaries, Future Practices: Doing Cultural Studies Inside the U.S. Warmachine, Santa Cruz: New Pacific Press, pp. 77-108.

Csordas, Thomas J. (1994) Embodiment and Experience: The Existential Ground of Culture and Self, New York: Cambridge University Press.

De Landa, Manuel (1997) A Thousand Years of Nonlinear History, New York: Zone Books.

Debord, Guy (1981) 'Perspectives for Conscious Alterations in Everyday Life', in K. Knabb (ed.), Situationist International Anthology, Berkeley: Bureau of Public Secrets, pp. 68-75.

Deleuze, Gilles (2001) 'Dualism, Monism and Multiplicities (Desire-PleasureJouissance)', Contretemps, 2, pp. 92-108, http://www.usyd.edu.au/contretemps/ contretemps2.html (accessed February 2007).

Deleuze, Gilles and Félix Guattari (1987) A Thousand Plateaus: Capitalism and Schizophrenia, trans. Brian Massumi, Minneapolis: University of Minnesota Press.

Dyer-Witheford, Nick (2006) 'Species-being and the New Commonism: Notes on an Interrupted Cycle of Struggles', The Commoner, 11, pp. 15-32.

Eco, Umberto (1989) The Open Work, trans. Anna Cancogni, Cambridge, MA: Harvard University Press. 


\section{Dimitris Papadopoulos}

Engels, Friedrich (1987 [1878]) 'Anti-Dühring. Herr Eugen Dühring's Revolution in Science', in K. Marx and F. Engels, Collected Works, vol. 25, London: Lawrence and Wishart.

Engels, Friedrich (1990 [1886]) 'Ludwig Feuerbach and the End of Classical German Philosophy', in K. Marx and F. Engels, Collected Works, vol. 26, London: Lawrence and Wishart.

Fausto-Sterling, Anne (2000) Sexing the Body: Gender Politics and the Construction of Sexuality, New York: Basic Books.

Gadamer, Hans-Georg (1989) Truth and Method, trans. Joel Weinsheimer and Donald G. Marshall (2nd revised edition), New York: Crossroad.

Gilbert, Jeremy (2008) Anticapitalism and Culture: Radical Theory and Popular Politics, Oxford: Berg.

Hall, Stuart (1986a) 'Gramsci's Relevance for the Study of Race and Ethnicity', Journal of Communication Inquiry, 10:2, pp. 5-27.

Hall, Stuart (1986b) 'On Postmodernism and Articulation: An Interview with Stuart Hall', Journal of Communication Inquiry, 10:2, pp. 45-60.

Hall, Stuart (1990) 'Cultural Identity and Diaspora', in J. Rutherford (ed.), Identity: Community, Culture, Difference, London: Lawrence and Wishart, pp. 222-37.

Hall, Stuart and Tony Jefferson (1976) Resistance Through Rituals: Youth Subcultures in Post-war Britain, London: Hutchinson.

Haraway, Donna J. (1997) Modest_Witness@Second_Millennium: FemaleMan@_ Meets_OncoMouse ${ }^{\mathrm{TM}}$ : Feminism and Technoscience, New York: Routledge.

Haraway, Donna J. (2007) When Species Meet, Minneapolis: University of Minnesota Press.

Harré, Rom (1996) 'The Necessity of Personhood as Embodied Being', Theory and Psychology, 5, pp. 369-73.

Harvey, David (1990) The Condition of Postmodernity: An Enquiry into the Origins of Cultural Change, Oxford: Blackwell.

Holland, Eugene W. (2005) 'Desire', in C. J. Stivale (ed.), Gilles Deleuze. Key concepts, Chesham: Acumen, pp. 53-62.

Jameson, Fredric (1981) The Political Unconscious: Narrative as a Socially Symbolic Act, London: Methuen.

Jordan, Zbigniew A. (1967) The Evolution of Dialectical Materialism: A Philosophical and Sociological Analysis, London: Macmillan.

Laclau, Ernesto and Chantal Mouffe (1985) Hegemony and Socialist Strategy: Towards a Radical Democratic Politics, London: Verso.

Lefebvre, Henri (1991) Critique of Everyday Life, Vol. 1: Introduction, trans. John Moore, London: Verso.

Lenin, Vladimir I. (1961 [1902]) 'What Is To Be Done? Burning Questions of Our Movement', in V. I. Lenin, Collected Works, vol. 5, Moscow: Foreign Languages Publishing House, pp. 347-530.

Lenin, Vladimir I. (1970 [1908]) Materialism and Empirio-criticism: Critical Comments on a Reactionary Philosophy, Moscow: Progress Publishers.

Marx, Karl (1975 [1844]) 'Economic and Philosophical Manuscripts of 1844', in K. Marx and F. Engels, Collected Works, vol. 3, London: Lawrence and Wishart.

Marx, Karl and Friedrich Engels (1976 [1846]) 'The German Ideology', in K. Marx and F. Engels, Collected Works, vol. 5, London: Lawrence and Wishart.

Mouffe, Chantal (2000) The Democratic Paradox, London: Verso.

Müller, Heiner (2000) 'Kinder, denkt an die Zwangsläufigkeit, Freiheit, Korruption, Konterrevolution: Ein Gespräch zwischen Sascha Anderson, Heiner Müller und A. R. Penck vor zehn Jahren', Frankfurter Allgemeine Zeitung, BS 3, Januar 20.

Negri, Antonio (2005) The Politics of Subversion: A Manifesto for the Twenty-first Century, trans. James Newell, Cambridge: Polity. 
Overton, Willis F. (1998) 'The Arrow of Time and Cycles of Time: Concepts of Change, Cognition and Embodiment', Psychological Inquiry, 5, pp. 215-37.

Papadopoulos, Dimitris (2006) 'World 2: On the Significance and Impossibility of Articulation', Culture, Theory and Critique, 47:2, pp. 165-79.

Papadopoulos, Dimitris (2010) 'Insurgent posthumanism', Ephemera: Theory and Politics in Organization.

Papadopoulos, Dimitris (forthcoming 2011) 'Alter-ontologies: Towards Constituent Politics in Technoscience', Social Studies of Science.

Papadopoulos, Dimitris, N. Stephenson and V. Tsianos (2008) Escape Routes: Control and Subversion in the Twenty-first Century, London: Pluto Press.

Protevi, John (2001) Political Physics: Deleuze, Derrida, and the Body Politic, London: Athlone.

Puig de la Bellacasa, Maria (2010) 'Ethical Doings in Naturecultures', Ethics, Place and Environment, 13:3.

Puig de la Bellacasa, Maria (in press) 'Matters of Care in Technoscience: Assembling Neglected Things', Social Studies of Science.

Rorty, Richard (ed.) (1967) The Linguistic Turn: Essays in Philosophical Method, Chicago: University of Chicago Press.

Sahlins, Marshall D. (2002) Waiting for Foucault, Still, Chicago: Prickly Paradigm Press.

Sedgwick, Eve K. (1990) Epistemology of the Closet, Berkeley: University of California Press.

Shapin, Steven (2008) The Scientific Life: A Moral History of a Late Modern Vocation, Chicago and London: University of Chicago Press.

Shapin, Steven and Simon Schaffer (1985) Leviathan and the Air-pump: Hobbes, Boyle, and the Experimental Life, Princeton: Princeton University Press.

Slack, Jennifer D. (1996) 'The Theory and Method of Articulation in Cultural Studies', in D. Morley and K.-H. Chen (eds.), Stuart Hall: Critical Dialogues in Cultural Studies, London: Routledge, pp. 112-27.

Smith, Pamela H. (2006) The Body of the Artisan: Art and Experience in the Scientific Revolution, Chicago: University of Chicago Press.

Spivak, Gayatri C. (1999) A Critique of Postcolonial Reason: Toward a History of the Vanishing Present, Cambridge, MA: Harvard University Press.

Stephenson, Niamh and Dimitris Papadopoulos (2006) Analysing Everyday Experience: Social Research and Political Change, London: Palgrave Macmillan.

Warner, Michael (1999) The Trouble With Normal: Sex, Politics, and the Ethics of Queer Life, New York: Free Press.

Williams, Raymond (1980) Problems in Materialism and Culture: Selected Essays, London: Verso.

Woolf, Virginia (1992) The Waves, London: Penguin Books. 